\title{
Properties of Self-compacting Concrete Produced with Biomass Wood Ash
}

\author{
Nenad RISTIĆ*, Zoran GRDIĆ, Gordana TOPLIČIĆ-ĆURČIĆ, Dušan GRDIĆ, Vladimir DODEVSKI
}

\begin{abstract}
The demand of the contemporary society for renewable energy sources lead to the increase of the bio-power plants. Accordingly, the amount of ash generated by burning the biomass is increased, and its disposal becomes a large environmental problem. The paper presents the research of potential use of biomass wood ash as a partial replacement for coal fly ash (10\%, $20 \%, 30 \%$ and $40 \%$ of mass) in production of self-compacting concrete (SCC). The effects of biomass wood ash on the properties of SCC in fresh and hardened states have been examined, as well as on the properties of durability. Test results indicated that the biomass wood ash slightly reduces the flowability and passing ability of SCC, while its addition enhances the viscosity of SCC and significantly prevents segregation and bleeding. SCCs with the contents of biomass wood ash up to $20 \%$ have approximately same mechanical strength as the reference mixture. Biomass wood ash has no negative effect on the resistance of concrete to the action of water under pressure, but a decrease of freeze/thaw resistance with de-icing salt is detected as its contents increases. The addition of biomass wood ash into SCC increases the drying shrinkage in the initial period of drying (up to 14 days), and it is decreased in a later phase.
\end{abstract}

Keywords: biomass wood ash; durability; fresh and hardened properties; self-compacting concrete

\section{INTRODUCTION}

Considering the progressive pollution of the environment and shortage of fossil fuels, there is a tendency in the contemporary society to maximize the use of renewable energy sources [1]. Resources of bioenergy coming from forestry and agricultural wastes are renewable energy sources with very low operational costs, which are continuously regenerated. Wood biomass is considered as a carbon neutral fuel as it absorbs the same amount of carbon dioxide while growing as released by burning it [2]. These are the reasons why the number of bioelectric power plants is increasing. Consequently, the amount of ash generated by the combustion of biomass also increases. Most of the ash is deposited in landfills, and a smaller portion is used as an addition to soil in agriculture or for various other uses [3-4]. Landfill disposed ash poses a risk to the environment due to the possibility of air and groundwater contamination and must be properly managed.

In the energy production process, using wood biomass, ash is generated, which can be classified as bottom ash (ash from the bottom of the incinerator) and fly ash (further divided into a coarse fraction (cyclone fly ash) and fine fraction (filter fly ash)) [5]. Chemical and mineral composition of wood can vary considerably and mostly depends on the type of wood, technology and burning temperature [6]. These properties of wood ash to a great extent determine the modes of its use.

In concrete production, there is a great potential to replace individual components with suitable alternative materials, including wood ash. If they are pozzolanically active then there can be a partial replacement of cement or an active mineral admixture to concrete [7]. Conversely, they can be used as inert filler as a replacement for sand or fine aggregate. Integration of wood ash into concrete can to a great extent contribute to solving the problem of its disposal.

There are studies that consider the potential and method of application of wood ash in the production of concrete and mortar [5, 8, 9, 10]. A general conclusion of these studies is that due to variations in chemical and mineralogical composition, detailed characterization of wood ash is required to determine the potential and method of its use as a partial replacement of cement or as a mineral admixture in cement composites.

There are numerous studies on the effect of partial replacement of cement by wood ash on the characteristics of mortar and concrete [11-19]. In terms of properties in the fresh state, studies have generally shown that only cement replacements up to $10 \%$ by mass had no negative effects. When the percentage of replacement is higher than $10 \%$, the impact of wood ash increases with increasing its content. It is the consequence of the fact that wood ash has a higher content of organic matter than cement or coal fly ash, which leads to a higher water absorption by wood ash during mixing and to variation of workability and consistency of mixtures. However, this negative effect can be solved using superplasticizers improving the workability without compromising the total quality of concrete.

The same studies on the effect of partial replacement of cement with wood ash indicated that mechanical strengths were reduced with the increasing percentage of wood ash. The authors concluded that partial replacement of cement by wood ash can be performed to a level of up to $20 \%$ in order to maintain mechanical strengths at an acceptable level. However, some of these studies have shown that $10 \%$ of cement replacement gives the best results for mechanical strengths. Barbosa et al. [16] studied the relationship between the curing period and compressive strength and noticed that wood ash delays the hydration process in the tested curing period of 60 and 90 days. Velay-Lizancos et al. [11] studied the effect of cement wood ash replacement on E-modulus at early ages of concrete ( 0 to 7 days). They found that at 7 days the impact of the $15 \%$ replacement was negligible, while during the first day the E-Modulus reduction was more than $70 \%$.

In terms of durability, replacement of cement with wood ash increases chlorides penetration of concrete. However, the decrease in this parameter was observed when wood fly ash was used mixed with another pozzolanic material as a cement replacement [20]. Cheah and Ramli [21] studied the carbonation depth of mortar containing high calcium wood fly ash as a cement replacement $(5-25 \%)$ and determined that only $5 \%$ of 
replacement contributed to the reduction of carbonation depth in comparison to control mortar. Wang et al. [20] showed that the presence of biomass ash does not appear to have a significant impact on the freezing and thawing behaviour with a proper amount of air entraining agent. Addition of chemical admixture for air entraining in concrete air can also increase freeze/thaw resistance with de-icing salt of concrete [22]. The effect of wood ash on the drying shrinkage of cement composites depends on the level of replacement of cement. Chean and Ramli [21] reported that replacement of up to $10 \%$ contributes to reduction of the total shrinkage of mortar, while the higher percentages of replacement of the total shrinkage were higher than the reference mortar.

There is a small number of studies about the use of wood as a replacement for fine aggregate or mineral additive [23-24]. Numerous studies have shown that waste powders with low pozzolanic activity can be successfully used as mineral admixtures for production of selfcompacting concrete [25-29]. Elinwa et al. [24] studied the impact of sawdust ash on the properties of SCC in fresh stated and concluded that adding the sawdust ash reduces workability of concrete, but that the increase of the amount of superplasticizer can achieve a satisfactory workability. There is insufficient data in the literature on the mechanical properties and properties of durability of self-compacting concrete with the addition of wood ash.

The main objective of this research is to examine the possibility of using biomass wood ash as a substitute for coal fly ash for the production of self-compacting concrete, as well as the effect of its addition on the properties of concrete in fresh and hardened state.

\section{EXPERIMENTAL RESEARCH}

\subsection{Materials Used in the Experiment}

The Portland cement CEM I 52.5 R and fly ash were used as the cementitious materials in the referenced SCC mixtures. Specific gravity and specific surface area of the used cement were $3.15 \mathrm{~g} / \mathrm{cm}^{3}$ and $4020 \mathrm{~cm}^{2} / \mathrm{g}$. respectively.

Table 1 Chemical composition of used cement, fly ash and biomass wood ash

\begin{tabular}{|c|c|c|c|}
\hline Parameter & Cement / \% & Fly ash / \% & $\begin{array}{c}\text { Biomass wood } \\
\text { ash /\% }\end{array}$ \\
\hline $\mathrm{SiO}_{2}$ & 19,30 & 51,68 & 4,45 \\
\hline $\mathrm{Fe}_{2} \mathrm{O}_{3}$ & 2,87 & 11,58 & 5,32 \\
\hline $\mathrm{Al}_{2} \mathrm{O}_{3}$ & 4,28 & 20,16 & 1,85 \\
\hline $\mathrm{CaO} /$ & 62,80 & 7,43 & 48,83 \\
\hline $\mathrm{MgO}$ & 2,20 & 2,41 & 6,62 \\
\hline $\mathrm{SO}_{3}$ & 3,05 & 2,02 & 2,11 \\
\hline $\mathrm{P}_{2} \mathrm{O}_{5}$ & 0,06 & 0,12 & 2,45 \\
\hline $\mathrm{TiO}_{2}$ & - & 1,04 & 0,11 \\
\hline $\mathrm{Na}_{2} \mathrm{O}$ & 0,21 & 0,88 & 0,46 \\
\hline $\mathrm{K}_{2} \mathrm{O}$ & 0,91 & 1,04 & 10,42 \\
\hline $\mathrm{LOI}$ & 2,26 & 2,57 & 12,24 \\
\hline
\end{tabular}

The fly ash in this study was a by-product obtained from a coal-fired power plant in Serbia. The used bottom biomass wood ash originates from the local biomass power plant. It was created by burning the driftwood of the hydroelectric power plant on the Danube. The biomass wood ash and fly ash were sieved through a $63 \mu \mathrm{m}$ sieve. Specific gravity and specific surface area of fly ash were $2.26 \mathrm{~g} / \mathrm{cm}^{3}$ and $3240 \mathrm{~cm}^{2} / \mathrm{g}$ respectively, while for biomass wood ash they amounted to $2.68 \mathrm{~g} / \mathrm{cm}^{3}$ and $5270 \mathrm{~cm}^{2} / \mathrm{g}$.
The chemical composition of the cement, fly ash and biomass wood ash used in our tests is given in Tab. 1, while in Fig. 1 their SEM and photograph are displayed.

A crushed gabbro was used as the coarse aggregates (fractions $4 / 8 \mathrm{~mm}$ and $8 / 16 \mathrm{~mm}$ ) and it had a specific gravity of $2890 \mathrm{~kg} / \mathrm{m} 3$ and water absorption of $0.58 \%$. River sand with a nominal maximum size of $4 \mathrm{~mm}$ (fraction $0 / 4 \mathrm{~mm}$ ), a specific gravity of $2620 \mathrm{~kg} / \mathrm{m}^{3}$ and water absorption of $1.42 \%$ was used as the fine aggregates.
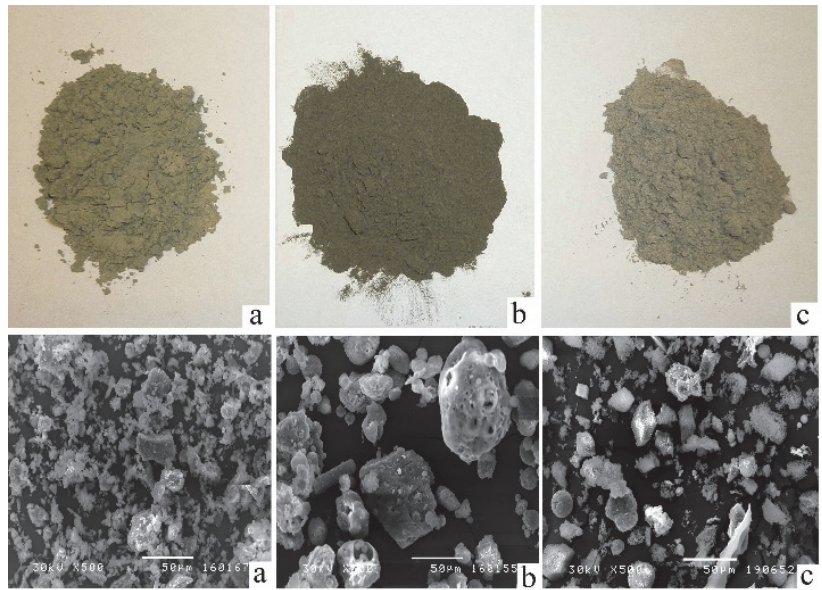

Figure 1 Photo (up) and SEM (down) display of used cement (a), fly ash (b) and biomass wood ash (c)

In this study. the superplasticizer used was a chemical admixture based on modified polystyrene esters (modified polycarboxylates).

\subsection{Concrete Mixture Composition}

To determine the effect of the addition of fly ash and biomass wood ash on the properties of cement paste, three standard pastes according to EN 196-3 were made: paste with $100 \%$ cement, paste with $75 \%$ cement and $25 \%$ fly ash (by mass) and paste with $75 \%$ cement and $25 \%$ biomass wood ash (by mass).

In order to compare the pozzolanic activity of the biomass wood ash with fly ash in mortar mixtures, three different mix proportions were designed in accordance with EN 450-1(listed in Tab. 2). In the test mixtures (FAAI and BWA-AI), $25 \%$ of the mass of cement used in the reference mixture named "E-AI" was replaced by fly ash and the biomass wood ash respectively.

Table 2 Mix proportion of mortar for testing Activity index

\begin{tabular}{|l|c|c|c|c|c|}
\hline Mix code & $\begin{array}{c}\text { Cement / } \\
\mathrm{g}\end{array}$ & Water /g & Fly ash /g & $\begin{array}{c}\text { Biomass } \\
\text { wood ash / } \\
\mathrm{g}\end{array}$ & $\begin{array}{c}\text { Standard } \\
\text { sand /g }\end{array}$ \\
\hline E-AI & 450 & 225 & - & - & 1350 \\
\hline FA-AI & 337,5 & 225 & 112,5 & - & 1350 \\
\hline BWA-AI & 337,5 & 225 & - & 112,5 & 1350 \\
\hline
\end{tabular}

In order to investigate the effects of using biomass wood ash to replace fly ash on properties of fresh and hardened self-compacting concrete, total of five concrete mixtures having different mass proportions between biomass wood ash and fly ash were designed. In these investigations, the reference mixture, named "E", consisted of cement, fly ash, sand and coarse aggregate. The biomass wood ash was used to replace fly ash at 10\%, 20\%, 30\% and $40 \%$ by weight correspondingly in $R_{10}, R_{20}, R_{30}$ and $R_{40}$ 
mixtures, respectively. All the concrete mixtures were made so as to have a similar slump-flow $700 \pm 20 \mathrm{~mm}$ (slump-flow classes SF2 according to The European Guidelines for Self-Compacting Concrete [30]) when concrete flowability is tested. This condition is met by varying the superplasticizer quantity. Mix proportion of SCC mixtures for $1 \mathrm{~m}^{3}$ of concrete is given in Tab. 3 .

Table 3 Mix proportion of SCC mixtures

\begin{tabular}{|c|c|c|c|c|c|c|}
\hline & $E$ & $R_{10}$ & $R_{20}$ & $R_{30}$ & $R_{40}$ \\
\hline \multicolumn{2}{|c|}{ Fine aggregate $0 / 4 \mathrm{~mm} / \mathrm{kg}$} & 830 & 830 & 830 & 830 & 830 \\
\hline \multirow{2}{*}{$\begin{array}{l}\text { Coarse } \\
\text { aggregate }\end{array}$} & $4 / 8 \mathrm{~mm} / \mathrm{kg}$ & 250 & 250 & 250 & 250 & 250 \\
\hline & $8 / 16 \mathrm{~mm} / \mathrm{kg}$ & 580 & 580 & 580 & 580 & 580 \\
\hline \multicolumn{2}{|c|}{ Cement / kg } & 320 & 320 & 320 & 320 & 320 \\
\hline \multicolumn{2}{|c|}{ Fly ash / kg } & 220 & 198 & 176 & 154 & 132 \\
\hline \multicolumn{2}{|c|}{ Biomass wood ash / kg } & - & 22 & 44 & 66 & 88 \\
\hline \multicolumn{2}{|l|}{ Water / kg } & 200 & 200 & 200 & 200 & 200 \\
\hline \multicolumn{2}{|c|}{ Superplasticizer (SP) / kg } & 4,6 & 5,0 & 5,5 & 6,2 & 7,1 \\
\hline \multicolumn{2}{|c|}{ SP/binder / \% } & 0,85 & 0,93 & 1,02 & 1,15 & 1,31 \\
\hline \multicolumn{2}{|c|}{$\mathrm{w} / \mathrm{b}(($ water $+\mathrm{SP}) /$ binder $)$} & 0,379 & 0,380 & 0,381 & 0,382 & 0,384 \\
\hline
\end{tabular}

\subsection{Types of Tests}

The paste was submitted to standard consistency, setting time and soundness tests according to standard EN 196-3.

The activity index was used to evaluate the pozzolanic activity of used ashes. The compressive strength of six samples of the reference mixture and six samples of the test mixture at ages of 28 and 90 days, was determined. Activity index was calculated as the ratio (in percent) of the compressive strength of test mixture samples, to the compressive strength of reference mix samples, when tested at the same age.

The following tests were conducted on the fresh concrete: density according to EN 12350-6, slump flow test and $T_{500}$ spreading test according to EN 12350-8, passing ability using L-box test according to EN 12350-10 and the sieve segregation resistance test according to EN 1235011.

The tested physical properties of the hardened concrete were the density and water porosity of SCC by using a water displacement method according to EN 12390-7 and ultra sound pulse velocity according to EN 12504-4:2008 using the specimen cubes having sides of $15 \mathrm{~cm}$. The dynamic elasticity modulus of concrete was calculated using Eq. (1) [31]:

$$
E_{d}=\rho \cdot c^{2} \cdot \frac{(1+v) \cdot(1-2 \cdot v)}{1-v}
$$

where, $E_{d}$ - dynamic elasticity modulus of concrete (MPa), $\rho$ - hardened concrete density $\left(\mathrm{kg} / \mathrm{m}^{3}\right), c$ - ultra sonic pulse velocity $(\mathrm{km} / \mathrm{s})$ and $v$ - Poisson's ratio.; Poisson's ratio was assumed as 0.2 for all concrete mixtures.

Also tested were mechanical properties of concrete, the most important being compressive strength. This characteristic was tested according to EN 12390-3, on cube shaped specimens having sides of $15 \mathrm{~cm}$ at the age of 2, 7, 28 and 90 days. The flexural strength test was performed on the prism shaped specimens, having dimensions $10 \times 10$ $\times 40 \mathrm{~cm}$ at the age of 28 and 90 days according to EN 12390-5. The splitting tensile strength test (Brazilian test) was performed on cylindrical specimens having diameter $\varnothing 15 \mathrm{~cm}$ and length $30 \mathrm{~cm}$ at the age of 28 and 90 days according to EN 12390-6. Determination of secant modulus of elasticity in compression was performed on cylindrical specimens having diameter $\varnothing 15 \mathrm{~cm}$ and length $30 \mathrm{~cm}$ at the age of 28 days according to EN 12390-13.

Also tested were properties of durability of concrete. Depth of penetration of water under pressure in hardened concrete was performed according to EN 12390-8 on the cubes having sides $15 \mathrm{~cm}$. During the test, the specimens were exposed to water under pressure of $500 \mathrm{kPa}$ for $72 \mathrm{~h}$. Determination of freeze/thaw resistance with de-icing salt of concrete was performed according to CEN/TS 12390-9 [32] on the slabs having dimensions $15 \times 15 \times 5 \mathrm{~cm}$ cut out from concrete cubes. A total of 56 freezing and thawing cycles were performed. Drying shrinkage of concrete was performed on the prism shaped specimens, having dimensions $10 \times 10 \times 50 \mathrm{~cm}$ according to UNI 11307 [33].

\section{RESULTS AND DISCUSSION \\ 3.1 Testing on the Cement Paste}

Test results on cement paste are given in Tab. 4. Test results showed that fly ash and biomass wood ash pastes had a greater demand for water to obtain a standard consistency than paste with $100 \%$ cement, where the water demand was significantly higher in the case of the biomass wood ash. This is probably because biomass wood ash is more porous and has a higher organic content and a higher specific surface area. Also, the presence of both types of ash in the cement paste prolongs the initial and final setting time, with wood ash having a slightly greater impact than fly ash. Higher percentage of $\mathrm{MgO}$ in ashes is a possible cause of the increase of the setting time, since the increased content of $\mathrm{MgO}$ retards initial hydration of cement [34]. Wood ash paste had the highest value of Soundness, probably because of the higher $\mathrm{CaO}$ content in it. In general, both types of ash meet the criteria of EN 450-1 for setting time and soundness.

Table 4 Results of testing on the cement paste
\begin{tabular}{|l|c|c|c|c|}
\hline \multicolumn{1}{|c|}{ Properties } & 100CEM & $\begin{array}{c}\text { 75CEM+ } \\
\text { 25FA }\end{array}$ & $\begin{array}{c}\text { 75CEM+ } \\
\text { 25BWA }\end{array}$ & $\begin{array}{c}\text { Requirement } \\
\text { s EN 450-1 }\end{array}$ \\
\hline $\begin{array}{l}\text { Standard } \\
\text { consistence / \% }\end{array}$ & 29,0 & 32,0 & 41,0 & - \\
\hline $\begin{array}{l}\text { Setting time / } \\
\text { min }\end{array}$ & $\begin{array}{c}\text { initial 115 } \\
\text { final 150 }\end{array}$ & $\begin{array}{c}\text { initial 170 } \\
\text { final 215 }\end{array}$ & $\begin{array}{c}\text { initial 180 } \\
\text { final 230 }\end{array}$ & $\begin{array}{c}<2 \times \\
100 \mathrm{CEM}\end{array}$ \\
\hline Soundness / mm & 1,0 & 0,5 & 3,0 & $<10,0$ \\
\hline
\end{tabular}

\begin{tabular}{|c|c|c|c|c|}
\hline \multirow[t]{2}{*}{ Mix code } & \multicolumn{2}{|c|}{$\begin{array}{c}\text { Compressive strength / } \\
\mathrm{MPa}\end{array}$} & \multirow{2}{*}{$\begin{array}{c}\text { Activity index / } \\
\%\end{array}$} & \multirow{2}{*}{$\begin{array}{c}\text { Requirement } \\
\text { s EN 450-1 } \\
\%\end{array}$} \\
\hline & 28 days & 90 days & & \\
\hline E-AI & 53,8 & 57,6 & - & \multirow{3}{*}{$\begin{array}{l}28 \text { days }-75 \\
90 \text { days }-85\end{array}$} \\
\hline FA-AI & 51,6 & 57,2 & $\begin{array}{l}28 \text { days }-95,9 \\
90 \text { days }-99,3\end{array}$ & \\
\hline BWA-AI & 45,4 & 49,6 & $\begin{array}{l}28 \text { days }-84,4 \\
90 \text { days }-86,1\end{array}$ & \\
\hline
\end{tabular}

\subsection{Testing of Pozzolanic Activity}

The activity index of fly ash and biomass wood ash is presented in Tab. 5. The test results indicated that biomass wood ash has a lower pozzolanic activity in respect of fly ash, but it fully meets the criterion according to SRPS EN 450-1 standard. This might be due to the fact that the 
biomass wood ash contained many active components which presented the pozzolanic activity.

\subsection{Properties of Fresh SCC}

The test results of fresh SCC properties are given in Tab. 6 . The table provides mean values of the obtained test results.

Table 6 Characteristic concrete in fresh state

\begin{tabular}{|c|c|c|c|c|c|}
\hline \multirow{2}{*}{ Properties } & \multicolumn{5}{|c|}{ Test results } \\
\hline & $E$ & $R_{10}$ & $R_{20}$ & $R_{30}$ & $R_{40}$ \\
\hline Test $\mathrm{T}_{500}$ time $/ \mathrm{s}$ & 5,4 & 5,9 & 6,6 & 7,5 & 8,9 \\
\hline Test $\mathrm{T}_{\text {final }}$ time $/ \mathrm{s}$ & 19,3 & 22,2 & 24,1 & 26,7 & 30,3 \\
\hline Slump flow test / mm & 720 & 700 & 710 & 690 & 680 \\
\hline $\begin{array}{l}\text { L-box passing ratio } \\
\left(\mathrm{H}_{2} / \mathrm{H}_{1}\right) / \mathrm{mm} / \mathrm{mm}\end{array}$ & 0,92 & 0,89 & 0,85 & 0,82 & 0,80 \\
\hline $\begin{array}{c}\text { Testing segregation using } \\
\text { sieves } / \%\end{array}$ & 9,6 & 7,7 & 6,0 & 5,3 & 4,5 \\
\hline Density $/ \mathrm{kg} / \mathrm{m}^{3}$ & 2410 & 2400 & 2390 & 2385 & 2375 \\
\hline
\end{tabular}

As it was already said, all the concrete mixtures were made to have approximately same slump-flow (700 \pm 20 $\mathrm{mm}$ ) on the event of testing concrete flowability, which was achieved by implementing superplasticizer. The amount of superplasticizer required for each mixture to meet the target slam-flow value is presented in Tab. 3. As seen in Tab. 3, with an increased use of the biomass wood ash, an increased amount of superplasticizer was required. This might be the fact that the porous biomass wood ash had a higher water absorption property, rendering less water available for the flow spread.

$T_{500}$ test indicates the viscosity of concrete mixture, and represents the time in which the concrete achieves the flow of $500 \mathrm{~mm}$ when testing flowability. Based on the test results in Tab. 6, it can be concluded that with the increase of replacement percentage of fly ash by biomass wood ash the time $T_{500}$, as well as $T_{\text {final }}$ (time required for complete spread) increases. A higher viscosity is the result of the reduced amount of free water in the mixture due to the higher porosity and water absorption property of biomass wood ash.

The effects of the biomass wood ash replacement level on the filling ability were determined using L-box test. As it can be seen in Tab. 6 , with increase of biomass wood ash contents, the filling ability of SCC mixtures decreases, too. On the other hand, it should be noted that the replacement of fly ash by biomass wood ash significantly decreased the segregation. When the biomass wood ash replacement was increased from $10 \%$ to $40 \%$, the segregation ratio was reduced from $9.6 \%$ to $4.5 \%$. This might be attributed to the increased cohesiveness of SCC mixtures with a corresponding increase of the biomass wood ash content.

\subsection{Properties of Hardened concrete 3.4.1 Physical Properties}

The density, water porosity, ultra sonic velocity and dynamic modulus elasticity test results are shown in Tab. 7. Each value presented is the average of three measurements.

The hardened density slightly decreased with increasing biomass wood ash content. The maximum density of $2400 \mathrm{~kg} / \mathrm{m}^{3}$ was recorded for the reference sample $(0 \%$ biomass wood ash), whereas the minimum value of $2370 \mathrm{~kg} / \mathrm{m}^{3}$ was recorded for the $40 \%$ biomass wood ash $\left(R_{40}\right)$ sample. The density reduction was probably due to higher porosity of SCC mixtures with biomass wood ash.

Table 7 Density, total water absorption, ultra sonic velocity and dynamic elastic modulus of concrete mixtures

\begin{tabular}{|c|c|c|c|c|c|}
\hline \multirow{2}{*}{ Properties } & \multicolumn{5}{|c|}{ Test results } \\
\cline { 2 - 6 } & $E$ & $R_{10}$ & $R_{20}$ & $R_{30}$ & $R_{40}$ \\
\hline Density/ kg/m $\mathrm{m}^{3}$ & 2400 & 2395 & 2385 & 2380 & 2370 \\
\hline Porosity /\% & 5,92 & 6,10 & 6,22 & 6,50 & 8,12 \\
\hline $\begin{array}{c}\text { Total water absorption / } \\
\%\end{array}$ & 3,13 & 3,25 & 3,38 & 3,54 & 3,89 \\
\hline Ultra sonic velocity / km/s & 4,28 & 4,25 & 4,23 & 4,18 & 4,08 \\
\hline $\begin{array}{c}\text { Dynamic elastic modulus } \\
\text { / GPa }\end{array}$ & 39,57 & 38,93 & 38,41 & 37,43 & 35,51 \\
\hline
\end{tabular}

The porosities of SCC mixtures prepared with 10 to $30 \%$ biomass wood ash content were similar to the reference mixture. However, at $40 \%$ of biomass wood ash replacement, the porosity of the mixture was significantly increased. This might be attributed to the fact that with excessive biomass wood ash contents, the viscosity of SCC mixtures increased, and the capacity for self-compacting reduced.

The most important factors affecting ultra sonic velocity values of concrete are the concrete porosity, aggregate type and interfacial transition zone (ITZ) characteristics. As it can be seen in Tab. 7, ultra sound pulse velocity through SCC samples is slightly reduced with the increase of biomass wood ash. The maximum ultra sound pulse velocity of $4.28 \mathrm{~km} / \mathrm{s}$ was recorded for the reference sample $(E)$, whereas the minimum value of 4.08 $\mathrm{km} / \mathrm{s}$ was recorded for the $40 \%$ biomass wood ash $\left(R_{40}\right)$ sample.

The basic factors affecting dynamic modulus of elasticity of concrete are the properties of aggregate, cement paste and interfacial transition zone characteristics. Based on the results given in Tab. 7, with the increase of biomass wood ash contents in SCC the value of dynamic modulus of elasticity is reduced. The reference mixture $(E)$ had $1.6 \%$ higher value of the dynamic modulus of elasticity in comparison to the mixture with $10 \%$ of biomass wood ash $\left(R_{10}\right)$, that is, for $2.9 \%, 5.4 \%$ and $10.3 \%$ in comparison to the mixtures $R_{20}, R_{30}$ and $R_{40}$ respectively. Potential reason for reduction of ultra sound pulse velocity (which indirectly affected the dynamic modulus of elasticity) is higher porosity and the weaker quality of ITZ for SCC mixtures with biomass wood ash.

\subsubsection{Compressive Strength}

Test results of compressive strength of SCC mixtures at the age of 2, 7, 28 and 90 days are provided in Fig. 2. Each value presented is the average of three measurements. The results indicate that SCC mixtures made with incorporated biomass wood ash have a lower compressive strength than the reference mixture at 2 and 7 days. However, at 28 and 90 days the SCC mixture with $10 \%$ biomass wood ash $\left(R_{10}\right)$ had the highest compressive strength value (58.9 MPa and 79.8MPa), which was $1.4 \%$ i.e. $3.2 \%$ higher than the reference mixture $(E)$. At these ages, the $R_{20}$ mixture had an approximately same compressive strength as the reference mixture $(E)$. The 
SCC mixture with $30 \%$ biomass wood ash at 28 and 90 days had a lower compressive strength for $11,0 \%$ i.e. $6.2 \%$ in respect to the reference mixture, while in the $R_{40}$ mixture this difference was $16.4 \%$ i.e. $10.2 \%$. High strengths at longer curing ages of the mixtures with $10 \%$ and $20 \%$ biomass wood ash might be attributed to the internal curing provided by the biomass wood ash and to the higher compactness of concrete due to the reduced amount of free water in the mixture.

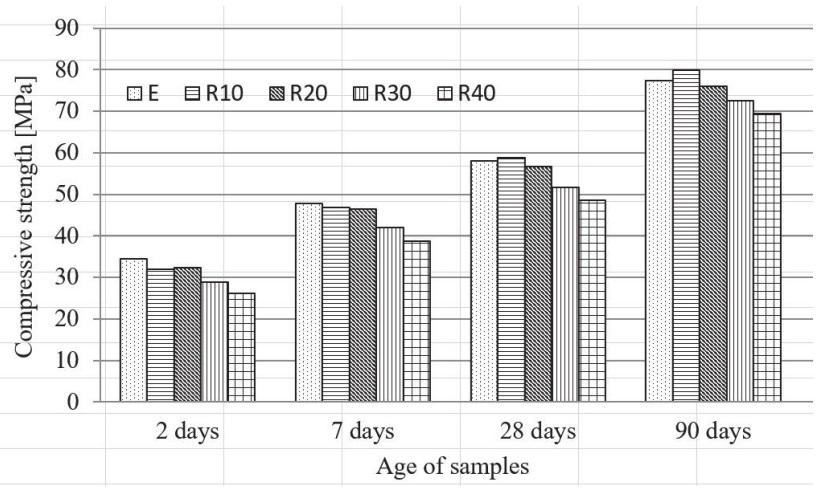

Figure 2 Compressive strength of SCC mixtures

\subsubsection{Flexural Strength}

The flexural strength test results of the concrete mixtures are shown in Fig. 3. Each value presented is the average of three measurements.

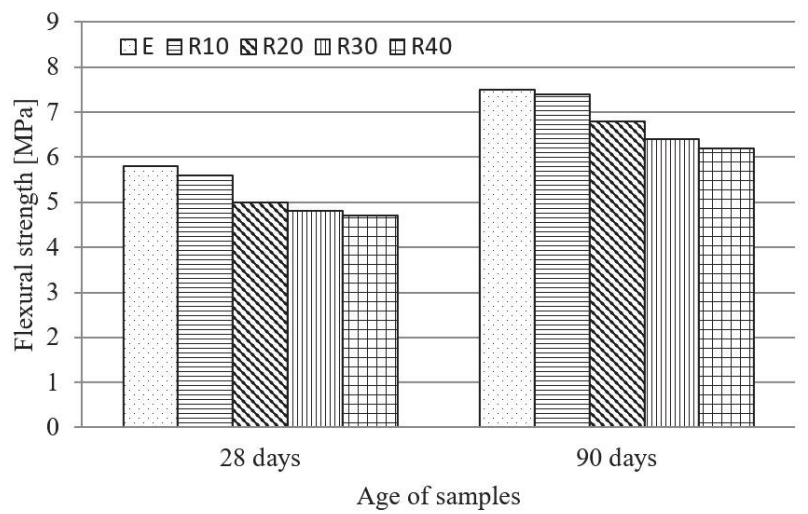

Figure 3 Flexural strength of SCC mixtures

The results indicated that the reference mixture $(E)$ had the highest flexural strength at 28 and 90 days (5.8 $\mathrm{MPa}$ and $7.5 \mathrm{MPa}$ respectively). Increasing the content of biomass wood ash in SCC mixtures, reduced the flexural strength at both ages of concrete. The decrease of strengths was the least between the mixtures E and $R_{10}(3.4 \%$ at 28 days and $1.3 \%$ at 90 days), while with the increase of the replacement percentage, this trend increased.

\subsubsection{Tensile Splitting Strength}

The splitting tensile strength test results of the concrete mixtures are given in Fig. 4. Each value presented is the average of three measurements. The results indicated that the SCC mixture with $10 \%$ biomass wood ash $\left(R_{10}\right)$ at 28 and 90 days had the highest value of tensile splitting strength (4.1 MPa and 4.9 MPa), which was $3.3 \%$ i.e. $4.3 \%$ higher than the reference mixture $(E)$. At these ages, the $R_{20}$ mixture had approximately the same tensile splitting strength as the reference mixture $(E)$. The SCC mixture $30 \%$ biomass wood ash $\left(R_{30}\right)$ at 28 and 90 days had a lower tensile splitting strength by $7.5 \%$, i.e. $10.6 \%$ in comparison to the reference mixture, while in the $R_{40}$ mixture, that difference amounted to $12.5 \%$ i.e. $14.9 \%$. High tensile splitting strength of mixture $R_{10}$ might be due to the internal curing offered by the biomass wood ash and better compactness of concrete.

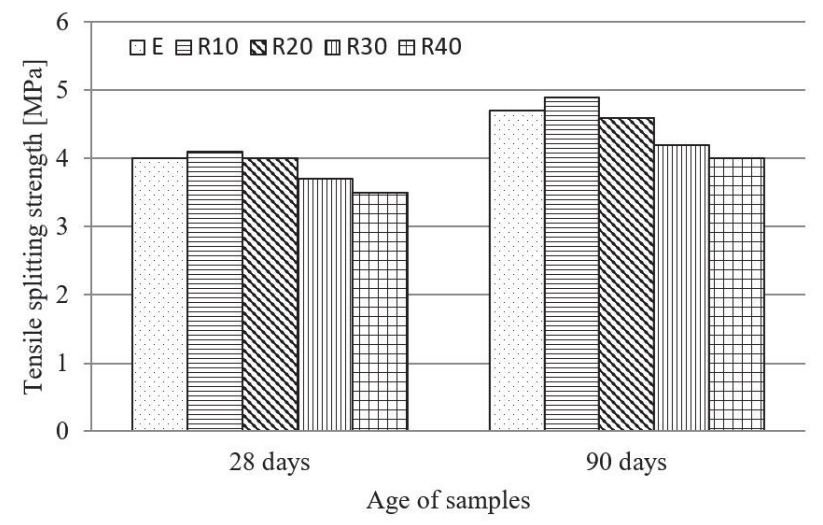

Figure 4 Tensile splitting strength of SCC mixtures

\subsubsection{Secant Modulus of Elasticity}

The most important factors affecting the value of secant modulus of elasticity of concrete are share, density and modulus of elasticity of basic components of concrete, porosity of coarse aggregate and cement paste, water/cement ratio, interfacial transition zone characteristics.

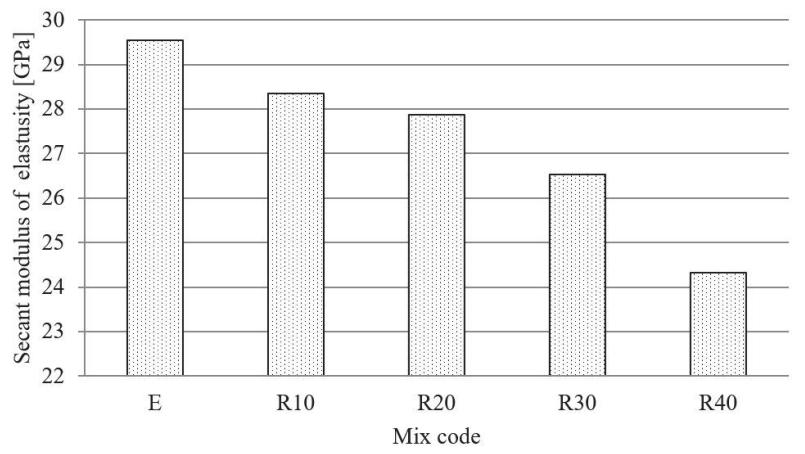

Figure 5 Secant modulus of elasticity of SCC mixtures at the age of 28 days

The effect of replacement of fly ash by biomass wood ash on the secant modulus of elasticity of the SCC mixtures at 28 days is illustrated in Fig. 5. Each value presented is the average of three measurements. The results indicated that with the increase of the biomass wood ash contents, the secant modulus of elasticity of SCC mixtures reduces. The highest value of the secant modulus of elasticity had the reference mixture 29.54 GPA which was $4.1 \%$ higher in respect to $R_{10}$, i.e. $6.6 \%, 10.2 \%, 17.6 \%$ in comparison to $R_{20}, R_{30}$ and $R_{40}$ respectively.

\subsubsection{Durability Properties of Concrete}

The depth of penetration of water under pressure in hardened concrete and freeze/thaw resistance with de-icing 
salt of concrete test results is shown in Tab. 8. Each value presented is the average of three measurements.

Table 8 Depth of penetration of water under pressure and freeze/thaw resistance with de-icing salt of SCC

\begin{tabular}{|c|c|c|c|c|c|}
\hline Mix code & $E$ & $R_{10}$ & $R_{20}$ & $R_{30}$ & $R_{40}$ \\
\hline $\begin{array}{c}\text { Depth of penetration of } \\
\text { water under pressure } / \mathrm{mm}\end{array}$ & 5 & 4 & 5 & 5 & 7 \\
\hline $\begin{array}{c}\text { Freeze/thaw resistance with } \\
\text { de-icing salt } / \mathrm{kg} / \mathrm{m}^{2}\end{array}$ & 0,14 & 0,19 & 0,26 & 0,35 & 0,42 \\
\hline
\end{tabular}

The test results of depth penetration of water under pressure showed that all tested SCC mixtures had the approximately same values of penetration $(4-7 \mathrm{~mm})$. In addition, and according to Neville and Brooks [31], these mixes can be considered as waterproof as none of them has a penetration greater than $30 \mathrm{~mm}$. It can be concluded that biomass wood ash does not have a negative effect on the resistance of SCC mixtures to the pressurized water action.

After 56 freezing-thaw cycles with de-icing salt, the least scaling of concrete surface was demonstrated by the reference mixture $(E)$. In Tab. 8 it can be seen that with the increase of biomass wood ash contents, the freeze/thaw resistance of concrete reduced. The $R_{10}$ mixture had an increased scaling in comparison to the reference mixture $(E)$, while the $R_{30}$ mixture had three times higher damage in respect to $E$. The possible reason is higher porosity and unfavourable pore structure of the SCC mixtures with biomass wood ash.

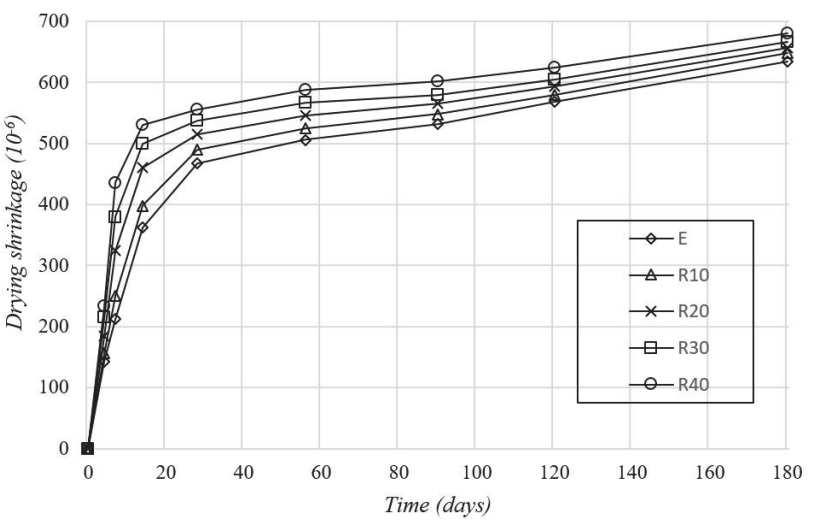

Figure 6 Drying shrinkage development of SCC mixtures

In Fig. 6 is presented the reduction of length owing to drying (drying shrinkage) of all SCC mixtures. At the age of 4 days there are no considerable differences in the shrinkage values. But, after 7 and 14 days there is a clear difference between the SCC mixtures made with different contents of biomass wood ash. It is noticed that the samples of concrete with biomass wood ash had higher values of drying shrinkage in respect to the reference sample. This effect is more pronounced with the increase of replacement percentage with fly ash by biomass wood ash. The rapid shrinkage could be due to the loss of water in the coarse capillary pores which were saturated during water curing. However, with ageing, the increase of drying shrinkage decreases and the final shrinkage becomes approximately the same as in the reference concrete. The possible reason for this might be attributed to the internal curing ability of the biomass wood ash. Biomass wood ash being a porous material absorbed a large amount of free water in the fresh state but the water gradually migrated from the biomass wood ash and was used for concrete curing particularly after the concrete had been dried for some time.

\subsubsection{SEM Observations}

The SEM was used to identify the microstructure characteristics interfacial transition zone (ITZ) and hardened cement paste. The potential non-uniformity and micro-cracks in the structure could result in a decrease of mechanical strengths, stiffness and permeability of concrete. In the ITZ there are usually multiple pores and non-hydrated cement particles, and for that reason more micro cracks will firstly form there and then propagate to the surface causing a brittle failure. In Fig. 7 are displayed SEM images of reference mixture and SCC mixtures with $20 \%$ and $40 \%$ biomass wood ash. It may be observed that the cement matrix of all the mixture is fairly uniform, without any clearly visible cracks or large pores. The crystallization has been almost complete, with no visible particles that failed to react which indicates that biomass wood ash did not have any adverse effects on hydration. However, the difference in the ITZ structure of the tested concretes was observed. Interfacial transition zone of reference mixture is well structured, providing good mechanical strength and properties of durability of this concrete. However, ITZ of SCC mixtures with biomass wood ash is not compact, i.e. it is not of good structure. It is characterized by the porosity which increases along with the increase of the biomass wood ash contents. Defects in ITZ are the possible reason of the decrease of mechanical strengths and freeze/thaw resistance with deicing salt of SCC mixtures with biomass wood ash.

\section{CONCLUSIONS}

In the present work, a study of the effects of replacement of fly ash by biomass wood ash on properties of fresh and hardened self-compacting concrete was carried out.

The results show that the biomass wood ash has satisfactory pozzolanic activity, but lower than fly ash. Also, the biomass wood ash slightly reduces the flowability and passing ability of SCC, with an increased requirement for superplasticiser in biomass wood ash concrete to meet the SCC requirements. However, the added biomass wood ash enhances the viscosity of SCC and significantly prevents segregation and bleeding.

In terms of the properties of SCC in the hardened state, the density negligibly decreases with the increase of contents of biomass wood ash, which is also the case for the dynamic modulus of elasticity. SCCs with the contents of biomass wood ash up to $20 \%$ have approximately same mechanical strengths as the reference mixture at all concrete ages, while strengths decrease with the increase of the fly ash replacement percentage. Secant modulus of elasticity mildly decreases with the increase of biomass wood ash contents.

Biomass wood ash does not have a negative impact on the resistance of concrete on the effect of water under pressure, but the decrease of freeze/thaw resistance with de-icing salt is detected, as the contents of biomass wood ash is increased. By adding biomass wood ash into SCC increases the drying shrinkage in the initial drying period 
(up to 14 days), and it is reduced at a later stage, which might be due to the internal curing effect.

The microscopic studies presented an insight into the ITZ characteristics and cement matrix structure. The results indicated that the addition of biomass wood ash did not negatively affect the structure of cement matrix which in all the mixtures was fairly uniform, without any clearly visible cracks or large pores. However, porosity of ITZ increased, that is, the compactness of its structure decreased with the increase of biomass wood ash which probably affected the decrease of mechanical strengths and freeze/thaw resistance with de-icing salt.

Comprehensively, the results of this research demonstrated that it is viable to use biomass wood ash as a partial replacement for coal fly ash for production of SCC. Observed from the aspect of practical use of SCC, it is recommended that the maximum replacement of coal fly ash by biomass wood ash is up to $30 \%$ by mass. Future research should be focused on the research of other properties of durability of SCC with biomass wood ash.
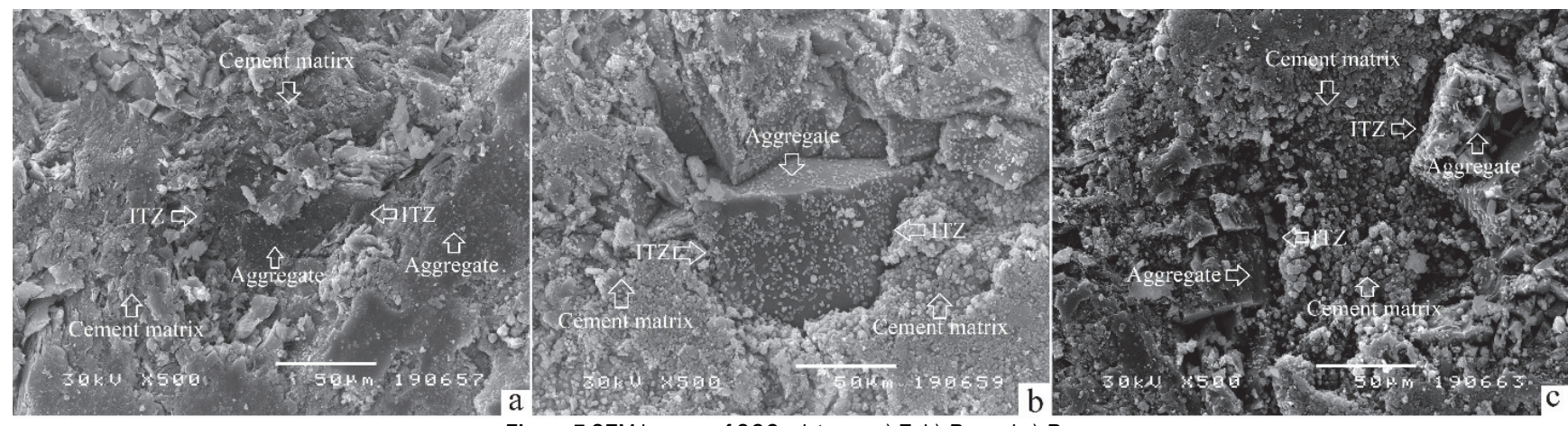

Figure 7 SEM images of SCC mixtures: a) E, b) $R_{20}$ and c) $R_{40}$

\section{Acknowledgements}

The work reported in this paper is a part of the investigation within the research project TR 36017 "Utilization of by-products and recycled waste materials in concrete composites in the scope of sustainable construction development in Serbia: investigation and environmental assessment of possible applications" supported by the Ministry for Science and Technology, Republic of Serbia. This support is gratefully acknowledged.

\section{REFERENCES}

[1] Directive 2009/28/EC of the European parliament and of the Council of 23 April 2009 on the promotion of the use of energy from renewable sources and amending and subsequently repealing Directives 2001/77/EC and 2003/30/EC, OJ L 140, 5.6.2009, pp. 16-62.

[2] Chowdhury, S., Mishra, M., \& Suganya, O. (2015). The incorporation of wood waste ash as a partial cement replacement material for making structural grade concrete: An overview. Ain Shams Engineering Journal, 6(2), 429437. https://doi.org/10.1016/j.asej.2014.11.005

[3] Vassilev, S. V., Baxter, D., Andersen, L. K., \& Vassileva, C. G. (2013). An overview of the composition and application of biomass ash.: Part 2. Potential utilisation, technological and ecological advantages and challenges. Fuel, 105, 19-39. https://doi.org/10.1016/j.fuel.2012.10.001

[4] Ban, C. C., Nordin, N. S. A., Ken, P. W., Ramli, M. \& Hoe, K. W. (2014). The high volume reuse of hybrid biomass ash as a primary binder in cementless mortar block.American Journal of Applied Sciences, 11(8) 1369-1378. https://doi.org/10.3844/ajassp.2014.1369.1378

[5] Milovanović, B., Štirmer, N., Carević, I., \& Baričević, A: (2019). Wood biomass ash as a raw material in concrete industry.Građevinar, 71(6), 505-514. https://doi.org/10.14256/JCE.2546.2018

[6] Chowdhury, S. Mishra, M., \& Suganya, O. (2015). The incorporation of wood waste ash as a partial cement replacement material for making structural grade concrete:
An overview.Ain Shams Engineering Journal, 6(2). 429437. https://doi.org/10.1016/j.asej.2014.11.005

[7] Kramar, S., \& Ducman, V., (2018). Evaluation of Ash Pozzolanic Activity by Means of the Strength Activity Index Test, Frattini Test and DTA/TG Analysis. Technical Gazette, 25(6). https://doi.org/10.17559/TV-20171203193229

[8] Teixeira, E. R., Camõesa, A., \& Branco, F. G. (2019). Valorisation of wood fly ash on concrete. Resources, Conservation \& Recycling, 145(6), 292-310. https://doi.org/10.1016/j.resconrec.2019.02.028

[9] Berra, M., Mangialardi, T., \& Paolini, A. E. (2015). Reuse of woody biomass fly ash in cement-based materials. Construction and Building Materials, 76, 286-296. https://doi.org/10.1016/j.conbuildmat.2014.11.052

[10] Naik, T. R. \& Kraus, R.N. (2003). Wood ash: a new source of pozzolanic materials. Center for By-Products Utilization.Report No. CBU-2001-11, REP-436. http://www.cbuuwm.info/Papers/2001\%20CBU\%20Report s/CBU\%202001-11.pdf

[11] Velay-Lizancos, M., Azenha, M., Lage, I. M., \& Burgo, P. V. (2017). Addition of biomass ash in concrete: Effects on E-Modulus, electrical conductivity at early ages and their correlation, Construction and Building Materials, 157, 1126-1132. https://doi.org/10.1016/j.conbuildmat.2017.09.179

[12] Carević, I., Štirmer, N., Pečur, I. B., Milovanović, B., Baričević, A., \& Rukavina, M. J. (2017).Potential of use wood biomass ash (WBA) inthe cement composities, $1^{s t}$ International Conference on Construction Materials for Sustainable Future, 19-21 April 2017, Zadar, Croatia, https://bib.irb.hr/datoteka/873226.POTENTIAL OF USE WOOD_BIOMASS_ASH_IN_THE_CEMENT_COMPOS ITES.pdf

[13] Ban, C. C. \& Ramli, M. (2011). The implementation of wood waste ash as a partial cement replacement material in the production of structural grade concrete and mortar: anoverview. Resources, Conservation \& Recycling, 55, 669685. https://doi.org/10.1016/j.resconrec.2011.02.002

[14] Barathan, S. \& Gobinath, B. (2013). Evaluation of wood ash as a partial replacement tocement. Int. J. Sci. Eng. Technol. Res., 2(10), 2009-2013.

https://pdfs.semanticscholar.org/3dca/25512100245ff787b6 09aa2ab5bc4a6e11a1.pdf 
[15] Batt, A. S. \& Garg, A. (2017). Partial replacement of wood ash with ordinary portland cement and foundry sand as fine aggregate. J. Civ. Environ. Eng., 07, 1-5. https://doi.org/10.4172/2165-784X.1000272

[16] Barbosa, R., Lapa, N., Dias, D., \& Mendes, B., (2013) Concretes containing biomass ashes:mechanical, chemical, and ecotoxic performances. Constr. Build. Mater., 48, 457463. https://doi.org/10.1016/..conbuildmat.2013.07.031

[17] Garcia, M. D. L. \& Sousa-Coutinho, J. (2013). Strength and durability of cement with forest waste bottom ash. Construction and Building Materials, 41, 897-910. https://doi.org/10.1016/j.conbuildmat.2012.11.081

[18] Yang, Z., Huddleston, J., \& Brown, H. (2016). Effects of Wood Ash on Properties of Concrete and Flowable Fill. Journal of Materials Science and Chemical Engineering, 4(7), 101-114. https://doi.org/10.4236/msce.2016.47013

[19] Maschio, S., Tonello, G., Piani, L., \& Furlani, E. (2011). Fly and bottom ashes from biomass combustion as cement replacing components in mortars production: Rheological behaviour of the pastes and materials compression strength, Chemosphere, 85(4), 666-671. https://doi.org/10.1016/j.chemosphere.2011.06.070

[20] Wang, S., Llamazos, E., Baxter, L., \& Fonseca, F. (2008). Durability of biomass fly ash concrete: freezing and thawing and rapid chloride permeability tests. Fuel, 87, 359-364. https://doi.org/10.1016/j.fuel.2007.05.027

[21] Cheah, C. B. \& Ramli, M. (2012). Mechanical strength, durability and drying shrinkage ofstructural mortar containing HCWA as partial replacement of cement. Construction and Building Materials, 30, 320-329. https://doi.org/10.1016/j.conbuildmat.2011.12.009

[22] Chen, S., Ren, J., Song, Y., Li, Q., Sun, J., Che, Y., \& Chen, J. (2019). Salt Freeze-Thaw Damage Characteristics of Concrete based on Computed Tomography. Tehnički vjesnik, 26(6), 1753-1763. https://doi.org/10.17559/TV-20190819080524

[23] Wang, S., Miller, A., Llamazos, E., Fonseca, F., \& Baxter, L. (2008). Biomass Fly Ash in Concrete: Mixture Proportioningand Mechanical Properties. Fuel, 87(3), 365371. https://doi.org/10.1016/j.fuel.2007.05.026

[24] Elinwa, A. U., Ejeh, P. S., \& Mamuda A. M. (2008). Assessing of the fresh concrete properties of self-compacting concrete containing sawdust ash. Construction and Building Materials, 22, 1178-82. https://doi:10.1016/j.conbuildmat.2007.02.004

[25] Janković, K., Šušić, N., Stojanović, M., Bojović, D., \& Lončar, Lj. (2017). The influence of tailings and cement type on durability properties of self-compacting concrete. Tehnički vjesnik, 24(3), 957-962. https://doi.org/10.17559/TV-20160304113800

[26] Ristić, N., Grdić, Z., Topličić Ćurčić, G., Grdić, D., \& Krstić, D. (2019). Properties of self-compacting concrete produced with waste materials as mineral admixture, Romanian Journal of Materials, 49 (4), 553-565. http://solacolu.chim.upb.ro/pg568-580.pdf

[27] Skazlić, M. \& Vujica, M. (2012), Environmentally-friendly self-compacting concrete. Građevinar, 64(9), 905-913 https://doi.org/10.14256/JCE.803.2012

[28] Krishnasamy, T. R. \& Murthi Palanisamy, M. (2015). Bagasse ash and rice husk ash as cement replacement in selfcompacting concrete. Građevinar, 67(1), 23-30. https://doi.org/10.14256/JCE.1114.2014

[29] Marinković, S., Protić, M., Paunović, S., Nešović, I., \& Bijeljić, J. (2018), Application of industrial by-products as mineral admixtures for self-compacting concrete. Građevinar, 70(1), 31-38 https://doi.org/10.14256/JCE.1516.2015

[30] The European Guidelines for Self-Compacting Concrete, Specification, Production and Use, (2005, May). http://www.efnarc.org/pdf/SCCGuidelinesMay2005.pdf
[31] Neville, A., Brooks, J. J. (2010). Concrete technology, $2^{\text {nd }}$ edition, Harlow, England Prentice Hall.

[32] CEN/TS 12390-9:2016 Testing hardened concrete Freezethaw resistance with de-icing salts. Scaling

[33] UNI 11307:2008 Testing for hardened concrete - Shrinkage determination, Ente Nazionale Italiano di Unificazione

[34] Altun, I. A. \& Yilmaz, I. (2002). Study on steel furnace slags with high $\mathrm{MgO}$ as additive in Portland cement. Cement and Concrete Research, 32(8), 1247-1249. https://doi.org/10.1016/S0008-8846(02)00763-9

\section{Contact information}

Nenad RISTIĆ, Ph.D., assistant prof.

(Corresponding author)

University of Nis,

Faculty of Civil Engineering and Architecture,

Aleksandra Medvedeva 14 street. 18000. Nis. Serbia

E-mail: nenad.ristic@gaf.ni.ac.rs

Zoran GRDIĆ, Ph.D., full prof.

University of Nis,

Faculty of Civil Engineering and Architecture,

Aleksandra Medvedeva 14 street. 18000. Nis. Serbia

E-mail: zoran.grdic@gaf.ni.ac.rs

Gordana TOPLIČIĆ-ĆURČIĆ, Ph.D., full prof.

University of Nis,

Faculty of Civil Engineering and Architecture,

Aleksandra Medvedeva 14 street. 18000. Nis. Serbia

E-mail: gordana.toplicic.curcic@gaf.ni.ac.rs

Dušan GRDIĆ, MScCE, assistant

University of Nis,

Faculty of Civil Engineering and Architecture,

Aleksandra Medvedeva 14 street. 18000 . Nis. Serbia

E-mail: dusan.grdic@gaf.ni.ac.rs

Vladimir DODEVSKI, Ph.D. Research Associate

University of Belgrade

Institute of Nuclear Science Vinca,

Mike Petrovica Alasa12-14 street. 11000 Belgrade, Serbia

E-mail: vladimir@vin.bg.ac.rs 